\title{
A METHOD OF MEASURING FRICTIONAL COEFFICIENTS OF WALK-WAY MATERIALS
}

\author{
By R. B. Hunter
}

ABSTRACT

This paper describes apparatus and methods for measuring coefficients of friction of walk-way surface materials. Conditions of the surface which affect the frictional coefficients of walk-way materials are examined, and data illustrating the precision obtainable by the methods described are given and discussed in their relation to the slipping hazard in walk-ways.

\section{CONTENTS}

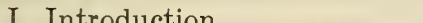

II. Purpose of the investigation 330

III. Materials investigated

IV. Methods employed . . 330

V. Preparation of worn surfaces _........... 331

1. The wearing apparatus_._.

2. Wearing process 332

VI. Friction measurements

1. Performance requirements of the apparatus........... 333

2. Description of apparatus.... 333

3. Friction test values ........... 333

4. Effect of smoothness of test surfaces_._._.

5. Effect of area of contact and pressure between surfaces_... 334

VII. Standardization of surface conditions... 336

1. Smoothness of test soles.......... 336

2. Effect of different leathers........ 337

3. Effect of humidity

4. Temperature and humidity control

5. Reproduction of test conditions....... 341

VIII. Simulated service conditions _...

1. Friction measurements under simulated service conditions_- 343

2. Test procedure on wet and oily surfaces..._. 344

IX. Discussion of friction data

$\mathrm{X}$. Summary of conclusions

\section{INTRODUCTION}

Project A-22 of the American Standards Association deals with the formulation of a safety code for walk-way surfaces. The sectional committee, which was organized to prepare this code, found the available data on walk-way surfaces and materials to be inadequate for the satisfactory formulation of a code, and appealed to the manufacturers for assistance in this connection. In response to this request, a manufacturers' subcommittee composed of a large group of manufacturers and distributors of walk-way materials was formed, and arrangements were made in July, 1924, for a research fellowship at the National Bureau of Standards to conduct an experimental investigation of the frictional resistances of walk-way surface materials. 
This investigation resulted in the development of an apparatus and process for preparing specimens of walk-way surface materials for friction measurements and an apparatus and methods for measuring coefficients of friction. A report of the investigation was submitted to the manufacturers' subcommittee in July, 1926.

Because of the incompleteness of the research it seemed advisable for the Bureau of Standards to conduct a further independent investigation of the problem, which was made by the former research associate in 1928 and 1929.

\section{PURPOSE OF THE INVESTIGATION}

The purposes of the original investigation were to develop a satisfactory method for measuring the frictional resistances of walk-way materials and to obtain data to aid the sectional committee in the formulation of a walk-ways safety code. The purposes of this paper are to describe the apparatus and methods developed in the earlier research, to review after the lapse of considerable time the data and the methods originally employed, and to examine these data as to their usefulness as a basis of evaluating the effectiveness of various materials in relation to the walk-ways safety problem.

\section{MATERIALS INVESTIGATED}

In the investigations of 1924-1926, friction measurements under different conditions were made on 148 specimens of walk-way and flooring materials. Specimens of most of the materials extensively used, as well as many less commonly employed in walk-way or floor surfaces, were included in this list. Twenty-four specimens, covering extreme ranges in hardness, smoothness, compressibility, absorptive power, and other characteristics affecting the coefficient of friction were chosen from these for the 1928-1929 investigation. In some cases two or more specimens of the same or of allied materials were chosen to afiord a closer study of their coefficients of friction.

Each of the 24 specimens is designated in the tables by a letter. These materials are roughly grouped according to their origin and physical characteristics as follows: Specimens C, D, E, F, G, I, and X are smooth-faced natural stone products, such as slate, marble, and travertine, with the exception of one specimen of vitrified tile; specimens Q, R, and S are wood, including smooth maple, larch, and yellow pine flooring; specimens T, W, P, and U are artificial stone products, some containing hard abrasive in the mixture; specimens $A, B, H, J$, and $\mathrm{K}$ are smooth-faced somewhat compressible manufactured products, such as rubber, cork carpet, and linoleum; specimens L, M, N, $\mathrm{O}$, and $\mathrm{V}$ are metal products having ridged or otherwise roughened surfaces, some containing embedded hard abrasive and others presenting a clear metal surface.

\section{METHODS EMPLOYED}

The safety or the slipping hazard offered by any given walk-way surface at a given time depends among other factors on the friction between the shoe sole and the walk-way surface at that time. The coefficient of friction is a direct measure of the resistance to slipping. 
The coefficient of friction is defined as the ratio of the force, $F$, required to slide one surface on the other, to the force, $F^{\prime \prime}$, pressing the two surfaces together, or $F / F^{\prime}$. When $F$ is the force required to start the motion, $F / F^{\prime}$ is the static coefficient of friction; and when $F$ is the force required to maintain a uniform motion, $F / F^{\prime}$ is the kinetic or dynamic coefficient of friction. In general, the static friction is the greater. The kinetic friction on some materials increases considerably with the velocity and may be greater than the static friction.

The law of friction may be stated as follows: The coefficient of friction between two given surfaces is a constant which is independent (within limits) of the area of contact and the force pressing the surfaces together. It is to be understood, however, that this constant applies only to two given surfaces. Another coefficient of friction may be obtained with other surfaces of the same materials.

There are a number of variable conditions which affect the coefficient of friction between a shoe sole and a walk-way surface-the smoothness of the shoe sole and the walk-way surface, the dryness of the two surfaces, and the presence of other substances between the two surfaces, as dirt, water, oil, etc. It consequently seemed advisable to measure the coefficients of friction of a variety of walk-way surface materials (1) under a standard or controlled surface condition and (2) under surface conditions simulating as nearly as possible actual service conditions, as a basis for determining the usefulness of friction measurements under controlled conditions.

For this purpose coefficients of friction were measured as follows: (1) Between clean, dry, oak-tanned leather soles and clean, dry, worn specimens of the walk-way materials; (2) between clean, wet, oaktanned leather soles and clean, wet, worn specimens of the walk way materials; (3) between dirty, wet, worn specimens of the wall-way materials and $(a)$ dirty, wet, oak-tanned leather soles and $(b)$ dirty, wet, rubber soles; and (4) between oily, worn specimens of the walkway materials and $(a)$ oily, oak-tanned, leather soles and $(b)$ oily rubber soles.

\section{PREPARATION OF WORN SURFACES}

It became evident from an examination of the surfaces of both new and service-worn specimens that friction measurements on new or unworn specimens of walk-way materials would give little indication of the relative antislip values of the materials in actual service. Some materials become smoother and some rougher under footwear. Measurements on the worn surfaces are therefore essential.

The time required to secure service-worn specimens and the uncertainty regarding their definite identification if taken from an old walk way render any attempt to obtain service-worn specimens for general tests impractical. An apparatus and process for producing accelerated wear in the laboratory are therefore essential.

\section{THE WEARING APPARATUS}

The apparatus shown in Figure 1 was constructed after preliminary tests with different abrasives and processes. It consists of a motordriven reciprocating arm carrying two square frames into which leather-soled, weighted shoes are loosely fitted. By means of a 
ratchet the shoes are slowly rotated. The reciprocating arm makes 34 transits per minute, and the shoes one complete revolution in 13 transits. The resultant motion is a slide and twist with a slight rocking motion of the shoe on the walk-way surface with each stroke. Dry sand (50 to 100 mesh) is fed slowly through two holes in each shoe, 4 inches apart. The rotation tends to keep the sand evenly distributed and to prevent scoring. It will be observed that while 50 to 100 mesh sand is fed continuously into the machine, the actual abrasive between the surfaces has somewhat different properties. The sand remains between the wearing surfaces for a time, becomes worn and crushed in the process, and mixes with the particles worn from the surfaces. The actual abrasive in use at any time is a mixture of fresh and crushed sand and dust from the sand, leather sole, and the walk-way material. Owing to the dust formed, it is advisable to have the abrasive machine inclosed in a dust-tight compartment with the motor and reducing gear outside.

\section{WEARING PROCESS}

The wearing process to which the walk-way materials were subjected may be divided into three parts:

1. All specimens were subjected to periods of wear with the abrasive described such that the surfaces were abraded by approximately equal amounts (about one-sixteenth inch in depth). Depending on the resistance of the materials to abrasion, these periods of wear varied from 10,000 to 80,000 transits of the shoe. Each specimen was rotated through $180^{\circ}$ in the middle of the process to insure more uniform wear.

2. Following part 1, the sand feed was removed and the sand and dirt wiped from the specimen and the shoe. The specimens were then subjected uniformly to 1,000 transits of the shoe without any abrasive. Each specimen was again rotated through $180^{\circ}$ in the middle of the process.

3. The specimens were then cleaned and finished by hand, as follows: They were washed under running water, wiping alternately with a wet cloth and the beveled edge of a picee of chrome-tanned sole leather to remove any embedded sand and encrusted dirt. They were then dried, and when thoroughly dry were dressed by rubbing first with a piece of No. $1 \frac{1}{2}$ sandpaper, then with a piece of No. 0 sandpaper. About 25 strokes in each of two directions at right angles with the sandpaper held on the open palm of the hand were given to each specimen with each kind of sandpaper. Finally, immediately before the friction measurement the specimen was rubbed in each of two directions with the beveled edge of a piece of oak-tanned sole leather and wiped with a dry cloth.

Trial specimens of several walk-way materials were prepared by these processes and compared with service-worn specimens of the same material by means of friction measurements. Some of these friction measurements are given in Table 1 . It will be observed that when the coefficient of friction of the service-worn and laboratory-worn specimens are compared with that of the unworn specimen the change is usually comparable in amount. This is believed to be the criterion by which the suitableness of the process should be judged. These seven materials cover extreme ranges in hardness, 
B. S. Journal of Research, RP204

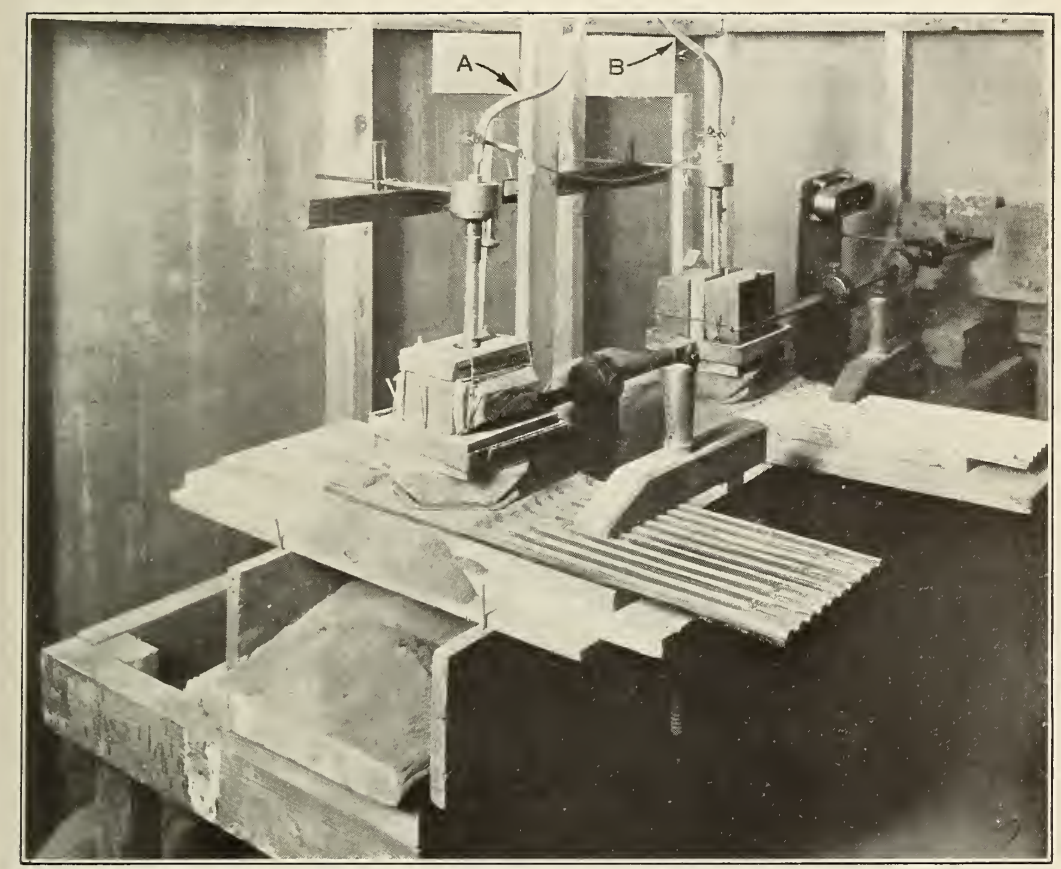

FIgURE 1.-Apparatus for preparing worn specimens

$A$ and $B$, rubber tubes leading to sand hopper. 


\section{B. S. Journal of Research, RP204}

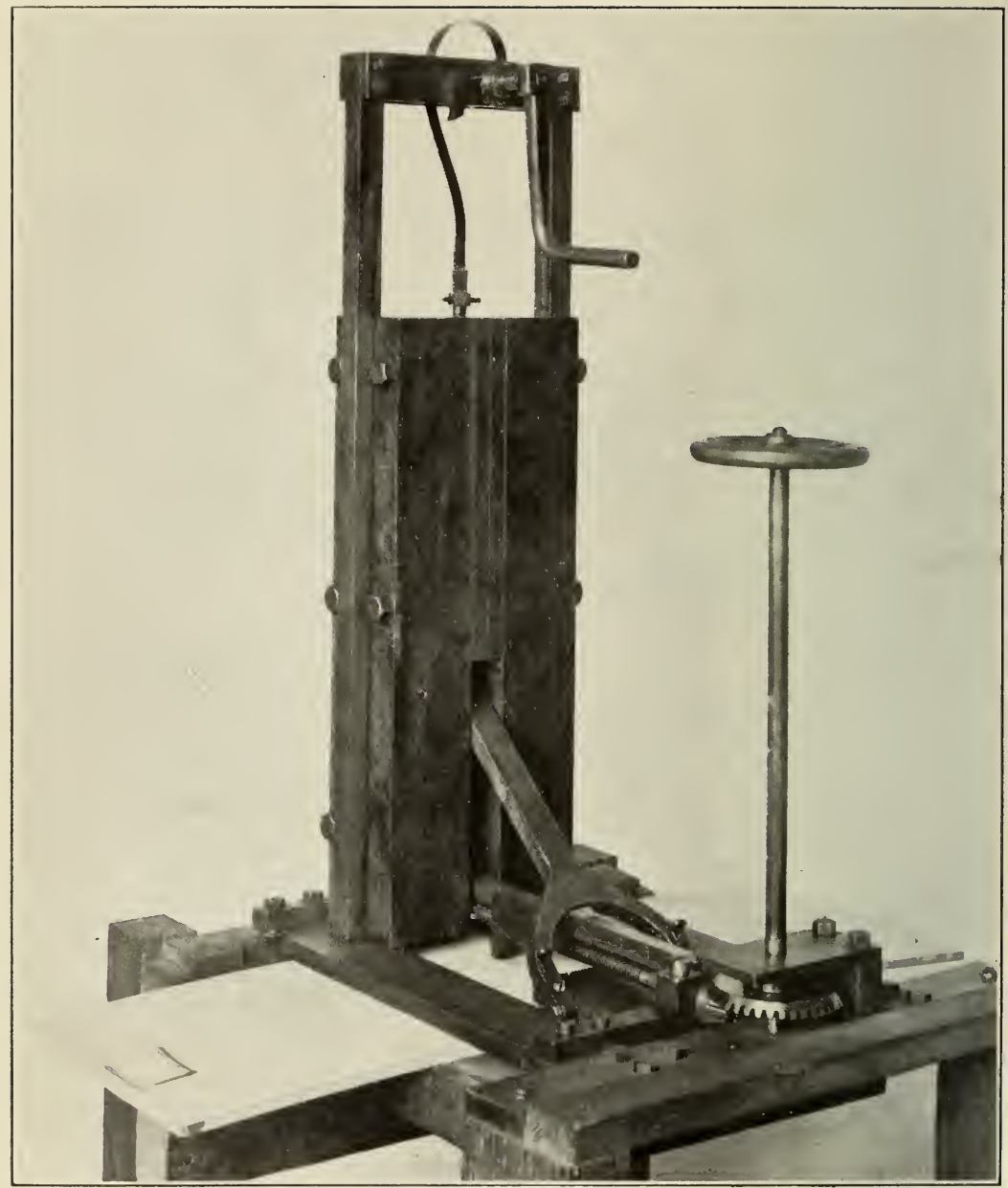

Figule 2.-F'riction measuring apparatus 
roughened surface contour, etc. 'The service-worn specimens were prepared for the test by washing, wiping with a cloth, and drying.

TABLE 1.-Friction measurements on service-worn and laboratory-worn specimens

\begin{tabular}{|c|c|c|c|c|c|c|c|}
\hline \multirow[b]{2}{*}{ Material No. } & \multicolumn{3}{|c|}{ Coefficients of friction } & \multirow[b]{2}{*}{ Material No. } & \multicolumn{3}{|c|}{ Coefficients of friction } \\
\hline & $\begin{array}{l}\text { On un- } \\
\text { worn } \\
\text { specimen }\end{array}$ & $\begin{array}{l}\text { On labora- } \\
\text { tory-worn } \\
\text { specimen }\end{array}$ & $\begin{array}{l}\text { On serv- } \\
\text { ice-worn } \\
\text { specimen }\end{array}$ & & $\begin{array}{l}\text { On un- } \\
\text { worn } \\
\text { specimen }\end{array}$ & $\begin{array}{l}\text { On labora- } \\
\text { tory-worn } \\
\text { specinen }\end{array}$ & $\begin{array}{l}\text { On serv- } \\
\text { ice-worn } \\
\text { specimen }\end{array}$ \\
\hline $\begin{array}{l}1 \\
1 \\
2 \\
3 \\
4 \\
4\end{array}$ & $\begin{array}{l}0.24 \\
.55 \\
.48 \\
.45\end{array}$ & $\begin{array}{r}0.29 \\
.29 \\
.31 \\
.29\end{array}$ & $\begin{array}{r}0.24 \\
.35 \\
.30 \\
.27\end{array}$ & $\begin{array}{l}5-\ldots \\
6- \\
7--\end{array}$ & $\begin{array}{r}0.48 \\
.42 \\
.23\end{array}$ & $\begin{array}{r}0.36 \\
.28 \\
.18\end{array}$ & $\begin{array}{r}0.30 \\
.28 \\
.20\end{array}$ \\
\hline
\end{tabular}

\section{FRICTION MEASUREMENTS}

\section{PERFORMANCE REQUIREMENTS OF THE APPARATUS}

Friction-measuring apparatus for walk-way materials should embody the following features:

1. It should be adapted to measurements on relatively small areas, to avoid the necessity of preparing large worn surfaces.

2 . The contact area between the surfaces should be comparable to the contact area between an average shoe sole and a walk way.

3. The standard load applied to the test sole should approximate the mean load applied to the shoe sole in walking.

4. The apparatus should be capable of duplicating measurements of the friction between unchanging surfaces.

\section{DESCRIPTION OF APPARATUS}

The apparatus shown in Figure 2 is simple in construction and manipulation and is believed to meet the peformance requirements enumerated. It operates on an oblique thrust principle corresponding to the thrust on the shoe in walking and consists of a right-angled frame carrying a slotted 75-pound weight between two vertical bars of the frame which serve as guides to the weight. A 10-inch thrust arm is pivoted at one end near the center of gravity of the weight and at the other end through the center of area of a 3 by 3 inch shoe. The weight may be raised by means of the windlass, and is supported in the raised position by the friction of the shoe on the surface under test. By means of a screw and lug the shoe may be drawn forward by small increments, increasing the horizontal component of the force until the shoe slips on the surface, letting the weight drop. The lug is left in the position at which the slip occurred. The lug carries an index which shows (on a scale graduated in inches) the horizontal distance of the shoe from its position when the thrust arm is vertical. This scale may be graduated to read in coefficients of friction directly if desired.

\section{FRICTION TEST VALUES}

The coefficient of friction is derived from the scale reading and the dimension of the apparatus. The vertical force, $F^{\prime}$ and the horizontal force $F$ acting on the shoe in any position are equal, respectively, to 
the vertical and horizontal components of the thrust transmitted to the shoe. In this case the coefficient of friction, or the ratio $F / F^{\prime}$, is equal to the tangent of the angle the thrust arm makes with the vertical at the point of slipping. The sine of this angle is one-tenth of the scale reading in inches. The tangent of the angle-that is, the coefficient of friction-may be obtained from a table of natural sines and tangents, or a table giving the coefficient of friction corresponding to any scale reading may be readily constructed. In making the measurements which follow, the reading on the scale graduated in 0.05 -inch divisions was taken to the nearest scale division, and the corresponding natural tangent representing the coefficient of friction was recorded to the nearest 0 or 5 in the third decimal place.

\section{EFFECT OF SMOOTHNESS OF THE TEST SURFACES}

The data in Table 2 were obtained from specimens freshly dressed but not rubbed with oak-tanned sole leather as previously described for the final dressing process. Twelve measurements were made on each specimen without redressing either the walk-way specimen or the test sole. It will be observed that when repeated measurements on the same specimen are thus made there is a continuous and fairly regular decrease in the coefficient of friction tending toward a constant minimum value. This decrease is evidently due to the smoothing of either the surface of the specimen or the surface of the test sole or both. For this reason a final dressing of the walk-way surface with leather and a standard preparation of the test sole is advised before beginning the friction measurements.

TABLE 2.-Typical values for repeated measurements

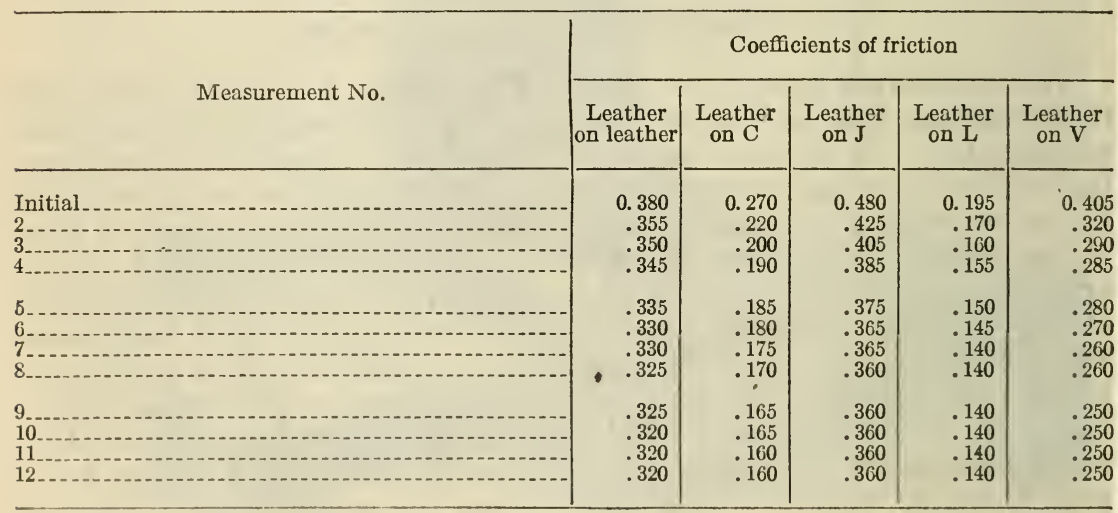

5. EFFECT OF AREA OF CONTACT AND PRESSURE BETWEEN SURFACES

While the law of friction states that the coefficient of friction between the same two surfaces is independent of the area of contact and the force pressing the surfaces together, some variation may be expected if these factors vary widely, and marked compression or abrasion of the materials occurs. The data in Tables 3 and 4 show that errors due to changes in area and load are negligible in comparison 
with other unavoidable discrepancies in measuring the coefficient of friction of walk-way materials. In Table 3 the first three measurements on each specimen were made with the standard 75-pound weight in the apparatus, the second three with the weight increased to 150 pounds, and the last three with the standard weight. The specimens were dressed for each series by the standard process described earlier and the sole for each series by a standard process later described. Each series of nine measurements on the same specimen was made without redressing or removing the specimen or shoe from the apparatus. In Table 4 the first three measurements were made with a standard 3 by 3 inch (9 square inches) sole, the second three with the same sole reduced to 1.5 by 3 inch ( 4.5 square inches) by cutting a strip from each side, and the last three with the sole again increased to standard size by replacing the strips. The sole and each specimen were redressed before each series of nine measurements as in Table 3. These four specimens were the same as used in Table 2 and represent for walk-way materials extreme ranges in hardness, compressibility, and roughness of surface.

TABLE 3.-Effect of weight

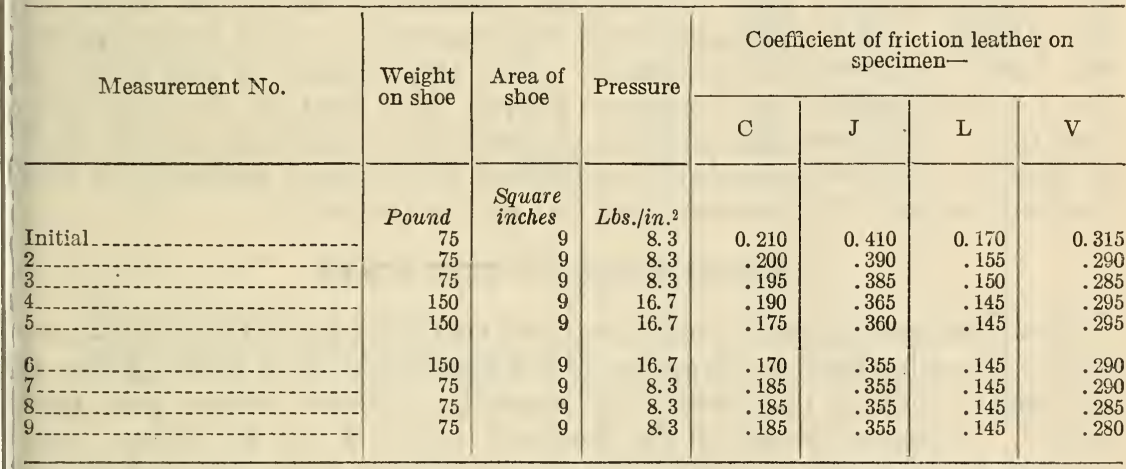

TABLE 4.-Effect of area of contact

\begin{tabular}{|c|c|c|c|c|c|c|c|}
\hline \multirow{2}{*}{ Measurement No. } & \multirow{2}{*}{$\begin{array}{l}\text { Weight } \\
\text { on shoe }\end{array}$} & \multirow{2}{*}{$\begin{array}{l}\text { Area of } \\
\text { shoe }\end{array}$} & \multirow{2}{*}{ Pressure } & \multicolumn{4}{|c|}{$\begin{array}{l}\text { Coefficient of friction leather on } \\
\text { specimen- }\end{array}$} \\
\hline & & & & $\mathrm{C}$ & $\mathrm{J}$ & $\mathrm{L}$ & V \\
\hline Initial & $\begin{array}{r}\text { Pound } \\
75 \\
75 \\
75 \\
75 \\
75\end{array}$ & $\begin{array}{c}\text { Square } \\
\text { inches } \\
9 \\
9 \\
9 \\
4.5 \\
4.5\end{array}$ & $\begin{array}{r}\text { Lbs./in. }{ }^{2} \\
8.3 \\
8.3 \\
8.3 \\
16.7 \\
16.7\end{array}$ & $\begin{array}{r}0.230 \\
.210 \\
.195 \\
.195 \\
.190\end{array}$ & $\begin{array}{l}0.425 \\
.405 \\
.390 \\
.395 \\
.390\end{array}$ & $\begin{array}{l}0.175 \\
.160 \\
.155 \\
.155 \\
.150\end{array}$ & $\begin{array}{l}0.320 \\
.295 \\
.275 \\
.275 \\
.275\end{array}$ \\
\hline $\begin{array}{l}6 \\
\\
8 \\
9 \\
9\end{array}$ & $\begin{array}{l}75 \\
75 \\
75 \\
75\end{array}$ & $\begin{array}{l}4.5 \\
9 \\
9 \\
9\end{array}$ & $\begin{array}{r}16.7 \\
8.3 \\
8.3 \\
8.3\end{array}$ & $\begin{array}{l}.190 \\
.190 \\
.190 \\
.190\end{array}$ & $\begin{array}{l}.385 \\
.385 \\
.375 \\
.375\end{array}$ & $\begin{array}{l}.145 \\
.145 \\
.145 \\
.145\end{array}$ & $\begin{array}{l}.275 \\
.290 \\
.285 \\
.280\end{array}$ \\
\hline
\end{tabular}

Comparing these data with the data of Table 2, it will be observed that the decrease in the coefficient of friction with varying weight or area of sole is almost as regular as with constant weight and constant 
area of sole, and that if the initial readings in Table 2 are discarded there is a fairly close agreement. The area of contact and the pressure do have some effect on the coefficient of friction when compression and abrasion are factors, but the effect is negligible in comparison with the variations due to other causes, such as the inability to reproduce surface conditions.

\section{STANDARDIZATION OF SURFACE CONDITIONS}

We have stated that smoothness, cleanness, and dryness are factors that affect the value of the coefficients of friction between two surfaces, and therefore it is necessary to standardize the test surfaces in respect to these factors in order to obtain results reproducible at another time with any degree of precision. This applies to both surfaces, the surface of the sole as well as the surface of the specimen.

Smoothness is a relative term. It is difficult to define exact degrees of smoothness and to reproduce them for standard tests. Coefficients of friction measured on relatively smooth surfaces will be more consistent than those measured on rougher surfaces.

The process previously described for preparing specimens for friction measurements does not exactly reproduce the same degree of smoothness even in the same walk-way material, but no better means has been discovered or proposed. The smoothness of the test sole can be standardized to a greater degree than that of the walk-way specimen. The test sole may be dressed by a standard process until it gives a selected standard coefficient of friction between it and another surface of the same material as the test sole.

\section{SMOOTHNESS OF TEST SOLES}

The standard adopted for oak-tanned leather soles in these measurements was obtained by dressing the leather sole on a piece of No. 0 sandpaper until a comparatively smooth, velvety surface was presented. Another piece of the leather, about 8 by 10 inches, was dressed in the same manner. The test sole was then operated in the friction-measuring apparatus until an approximately constant value of the coefficient of friction, 0.310 , between leather and leather was obtained. The number of operations in the friction apparatus required to reach 0.310 , the value of the coefficient of friction selected as indicating standard smoothness, depends on the smoothness of the initial dressing and apparently to some extent on the temperature and humidity.

The data in Table 5 give the coefficients of friction obtained in successive operations in typical runs in reducing the test sole to standard smoothness at different temperatures and relative humidities. In addition to the data for individual runs, the average initial readings and the average number of operations in the friction-measuring apparatus required to reach standard smoothness in 10 dressings of the sole are given. 
TABLE 5.-Coefficients of friction leather on leather obtained in reducing test soles to standard smoothness

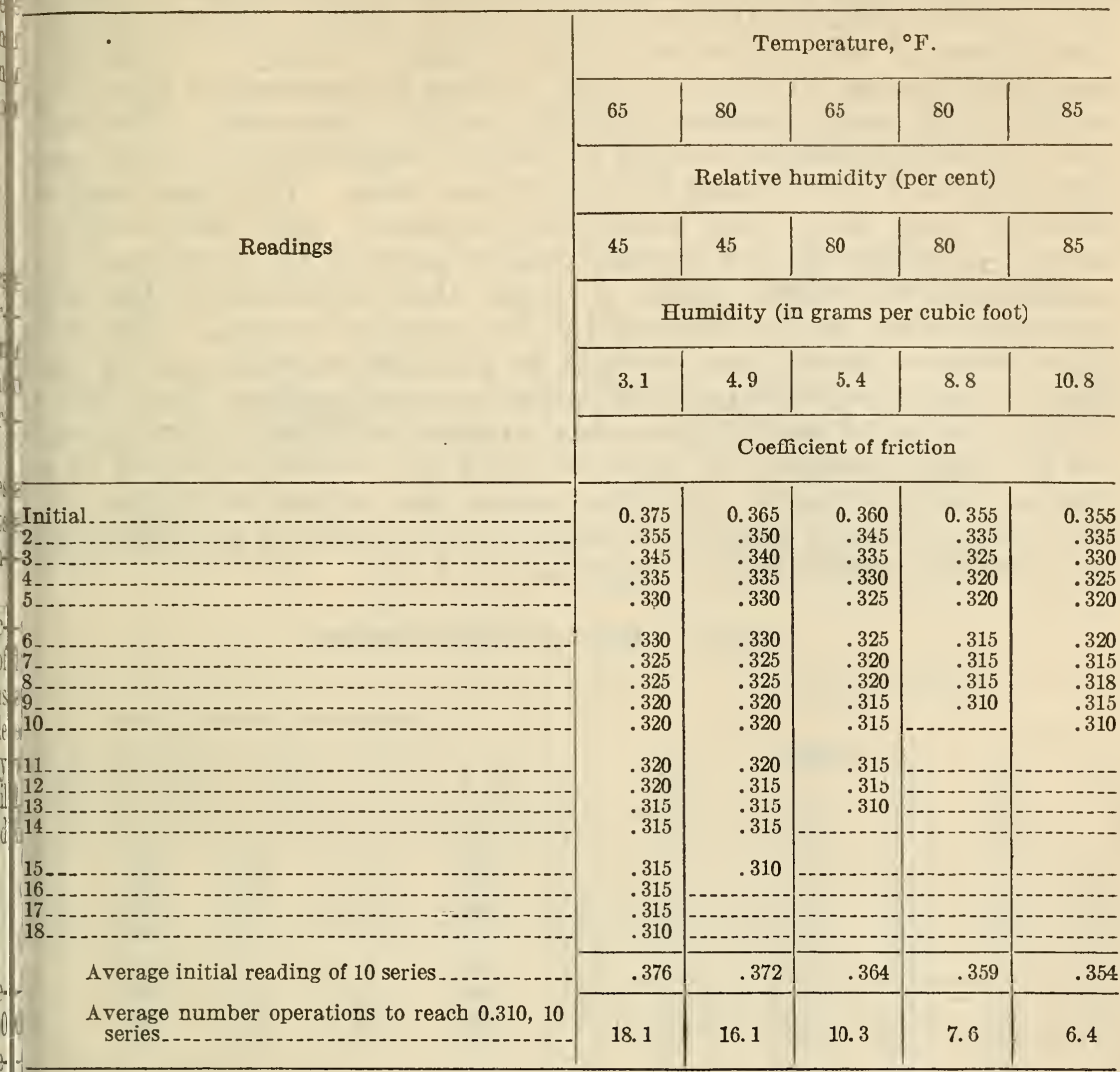

It is interesting to note that in these data the coefficient of friction between leather and leather apparently decreases with increase in absolute humidity. This is indicated both by the decrease in the coefficient of friction in the initial operation and by the decrease in the number of operations required to reach a value of 0.310 , as the absolute humidity increases. This is exactly opposite to the effect of humidity on the coefficients of friction between leather and most walk-way materials.

The process just described was employed in all later measurements under dry conditions unless otherwise stated, and the test sole was considered to have reached the standard condition of smoothness when the first reading giving a value of 0.310 for the coefficient of friction of leather on leather was reached. While it does not insure an aksolute standard of smoothness it is the best method discovered.

\section{EFFECT OF DIFFERENT LEATHERS}

The data in Table 6 illustrate the variation in the standard sole that may be expected due to the use of different test soles. Sole 4 was a clear firm piece of oak-tanned sole leather in excellent condition; sole 1 was a firm, clear piece of oak-tanned sole leather worn in 
tests until it showed a slightly hardened spot on one edge; sole 2 was a firm, clear piece of oak-tanned sole leather which had been worn in tests until it resisted the prescribed velvety finish; and sole 3 was a clear piece of oak-tanned sole leather slightly flanky in appearance and slightly worn in previous tests. These measurements were made at $70 \pm 2^{\circ} \mathrm{F}$. and a relative humidity of $65 \pm 2$ per cent. The walkway specimens had been stored in the laboratory for about two years after they had been dressed for the previous tests. They were washed, cleaned, and dried for these measurements, but their surfaces were not redressed, and for this reason some of the specimens give coefficients of friction higher or lower than obtained on the same specimen when freshly dressed by the standard process. The soles were freshly dressed and brought to standard smoothness for each test. The measurements were made on each specimen from left to right as recorded, and only one measurement with each sole ${ }^{\circ}$ was made on the same specimen in order to avoid the smoothing effect of repeated measurements. For this reason the values are higher than the average when a series of several tests are made on the same specimen without redressing the specimen and sole.

TABLE 6.-Effect of different leathers

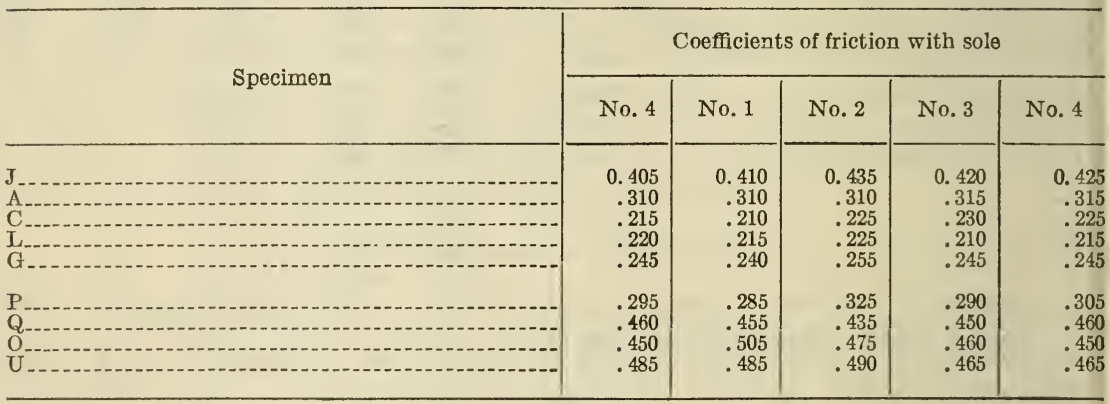

The duplicate measurements made on the same specimen with the same piece of leather (sole 4) differ from the mean by amounts varying from 0 to about 5 per cent. Of the 27 measurements made with soles 1, 2, and 3 only two measurements show a greater difference, and these two were obtained with soles which had been previously rejectod as standard because of obvious defects. It therefore seems reasonable to assume that if the soles are carefully selected from firm, clear pieces of leather the differences in the frictional properties of oak-tanned sole leathers are negligible in comparison with the mechanical differences in the smoothness of the surface obtainable by a standard process of dressing.

\section{EFFECT OF HUMIDITY}

The effect of temperature and relative humidity or of absolute humidity on the coefficient of friction has been pointed out. The data in Table 7 show the variation in the coefficient of friction which may occur on clean dry walk-way surfaces due to ordinary atmospheric changes in temperature and humidity in the interior of buildings. 'These measurements were taken in the order of increasing 
absolute humidity without redressing the walk-way specimen. The sole was redressed and brought to the standard value, 0.31 (leather on leather) before each measurement.

TABLE 7.-Variation in coefficients of friction with temperature and humidity

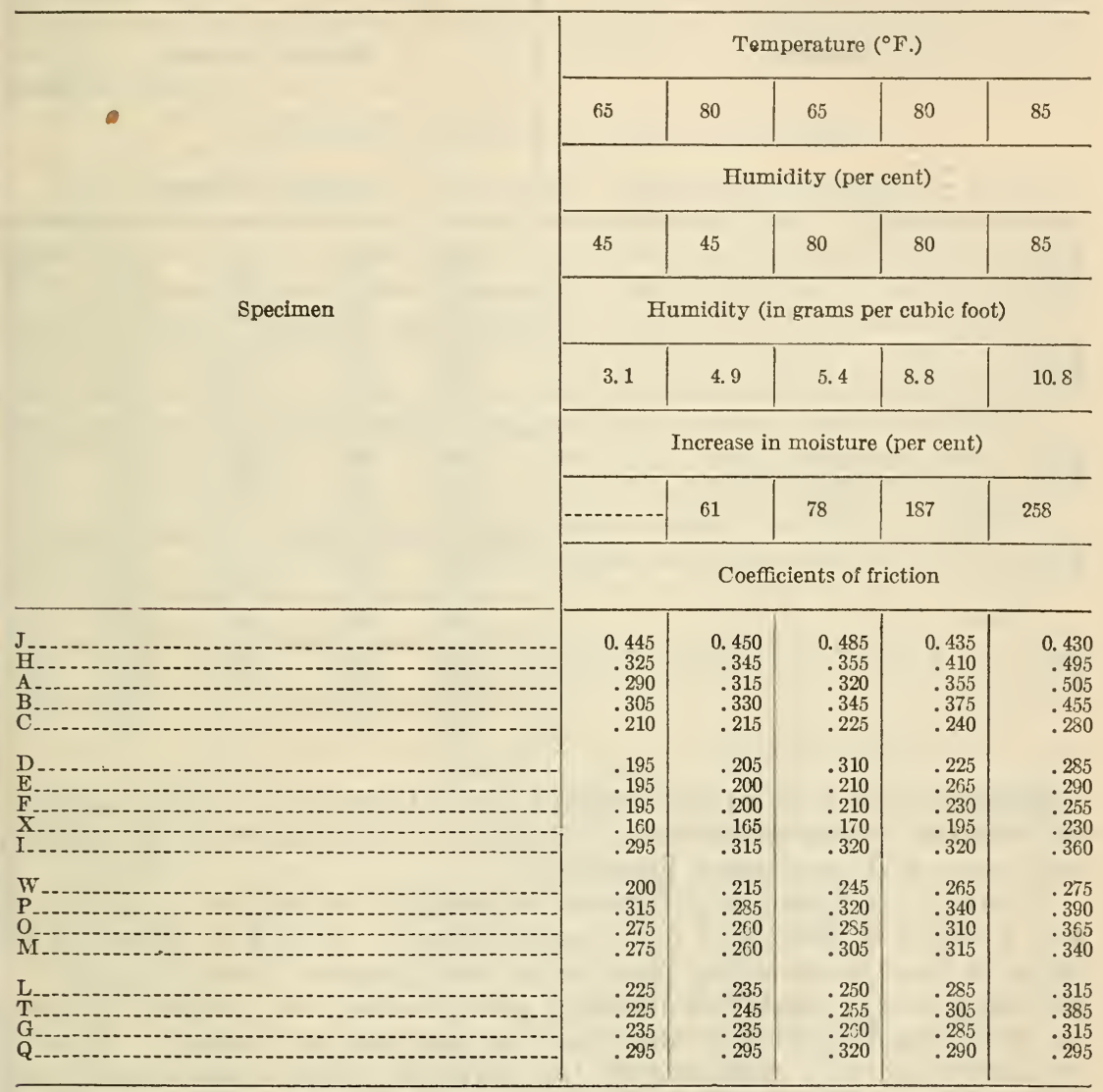

Of these specimens all except two show a marked increase in the coefficients of friction with increase in the absolute humidity. The two exceptions-one rubber tile and one wood flooring-show some indication of the opposite effect which, however, may be partly due to the smoothing effect of repeated measurements.

The measurements were made from left to right on each specimen without redressing it, in order to avoid erratic changes. Table 8 gives data for 5 specimens, 2 of rubber tile and 3 of wood, in which the measurements were made $(a)$ from left to right as before in the order of increasing humidity, and $(b)$ from right to left in the order of decreasing humidity, all without redressing the specimen. The mean of the two measurements at the same temperature and humidity should at least partially eliminate or average the smoothing effect. These rubber specimens were rubbed to a smoother finish than for the previous measurements of Table 7 and for that reason the coefficients of friction in Table 8 are generally lower.

$$
118793^{\circ}-30-9
$$


TABLE 8.-Effect of temperature and humidity

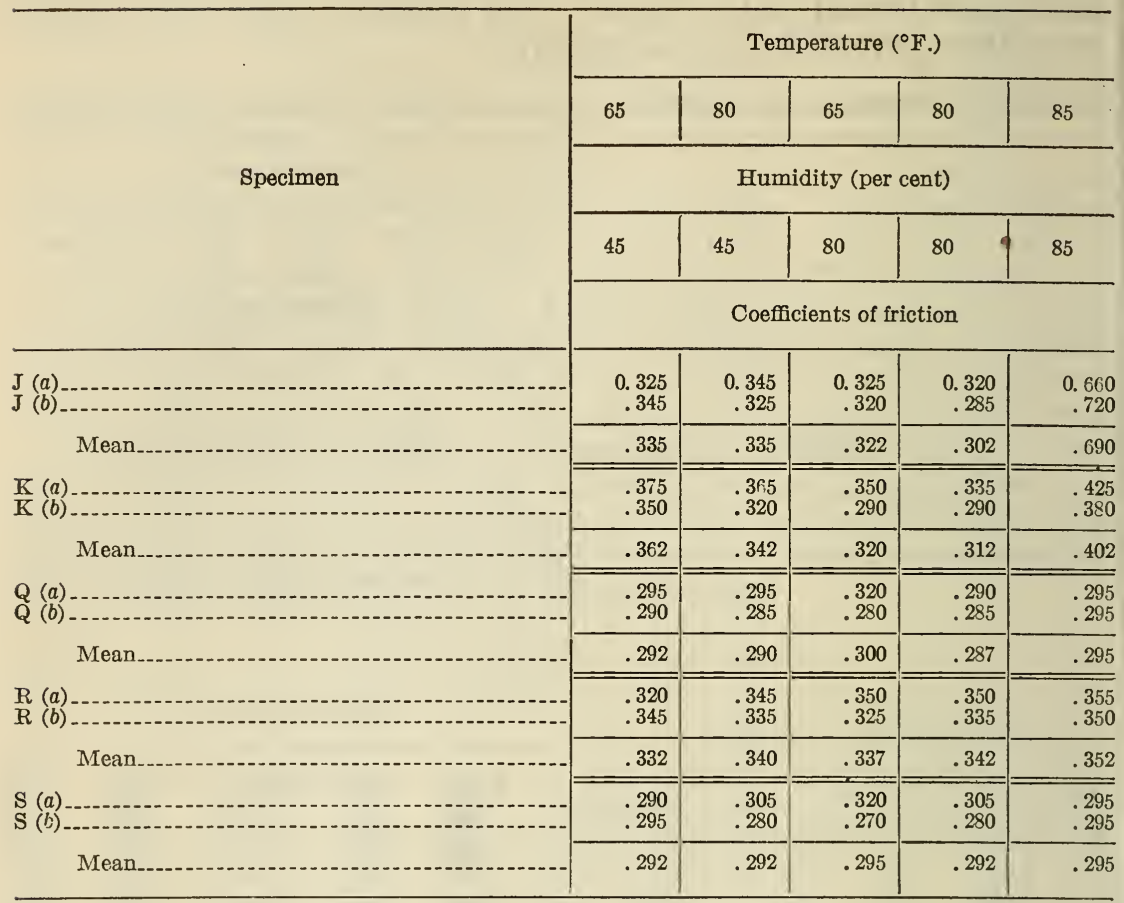

Judging from the data in Tables 7 and 8 there is no regular increase or decrease in the coefficients of friction of such materials as rubber and wood with increasing humidity.

There is one marked difference in the data on rubber in Tables 7 and 8 which is worthy of note and comment. It will be observed in Table 8 there is an abrupt rise in the coefficients of friction at $85^{\circ} \mathrm{F}$. and 85 per cent relative humidity, more marked on specimen $J$ than on specimen $K$, which is not shown in the data of Table 7 . This is probably due to a softening of the material under those conditions. In fact, specimen $J$ had a sticky feeling when the exceptionally high coefficients of friction were obtained. Other measurements made on specimens of rubber at the same and higher temperatures and humidities gave the same kind of erratic results.

There is no apparent explanation for this change in friction with change in humidity, and speculation regarding it seems to lead to no definite conclusion. Similar phenomena are observed in the behavior of brake bands, belts, and such devices in which the efficiency of operation depends on friction. The data show clearly, however, the necessity of controlling the temperature and humidity within rather narrow limits of variation, if reproducible values of the coefficient of friction are to be obtained.

\section{TEMPERATURE AND HUMIDITY CONTROL}

The data in the preceding Tables 7 and 8 and in Tables 9 and 10 following were made in a chamber in which the temperature was held constant within $\pm 2^{\circ} \mathrm{F}$. and the relative humidity within \pm 2 
per cent of the desired selected conditions. The walk-way specimens and the test soles were stored under each selected condition for at least four hours before the measurements were made. No regular change was detected in the coefficients of friction of any material taken from relatively dry storage and stored for that length of time under standard conditions, and four hours is believed to be sufficient time in which to attain a fairly constant condition in the surface layer.

\section{REPRODUCTION OF TEST CONDITIONS}

The data in Table 9 indicate the probable precision in friction measurements attainable by the methods described. These measurements were made on specimens prepared by the standard process previously described. Each specimen was subjected to part 3 of the process, hand dressing, immediately before starting each series of measurements. The sole was redressed and brought to the selected standard coefficient of friction of 0.31 on leather immediately before each series. Five successive measurements were made in each series without redressing the specimen or sole. All measurements were made at $70^{\circ} \pm 2^{\circ} \mathrm{F}$. and $65 \pm 2$ per cent relative humidity after the sole and specimen had been stored for at least four hours under that condition. The average for each series and the general average of these for each material are given.

TABLE 9.-Friction measurements at $70^{\circ} \pm 2^{\circ} \mathrm{F}$. and relative humidity of $65+2$ per cent

\begin{tabular}{|c|c|c|c|c|c|c|}
\hline \multirow[b]{2}{*}{ Specimen } & \multirow[b]{2}{*}{ Reading } & \multicolumn{5}{|c|}{ Coefficients of friction } \\
\hline & & Series 1 & Series 2 & Series 3 & Series 4 & $\begin{array}{l}\text { General } \\
\text { average }\end{array}$ \\
\hline $\begin{array}{l}\mathrm{X} \\
\mathrm{X} \\
\mathrm{X} \\
\mathrm{X} \\
\mathrm{X} \\
\mathrm{X}\end{array}$ & 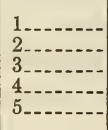 & $\begin{array}{r}0.205 \\
.170 \\
.165 \\
.160 \\
.160\end{array}$ & $\begin{array}{r}0.195 \\
.170 \\
.160 \\
.155 \\
.155 \\
\end{array}$ & $\begin{array}{l}0.195 \\
.165 \\
.155 \\
.150 \\
.150\end{array}$ & $\begin{array}{l}0.205 \\
.180 \\
.165 \\
.165 \\
.160\end{array}$ & \\
\hline Average. & & .172 & .167 & .163 & .175 & $\overline{0.169}$ \\
\hline 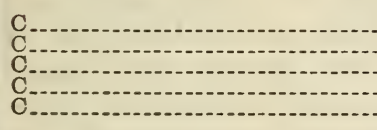 & $\mid \begin{array}{l}1 \\
2 \\
3 \\
4 \\
5-\cdots \\
5-\cdots-\cdots\end{array}$ & $\begin{array}{l}.205 \\
.170 \\
.160 \\
.155 \\
.150\end{array}$ & $\begin{array}{l}.200 \\
.165 \\
.165 \\
.165 \\
.165\end{array}$ & $\begin{array}{l}.205 \\
.170 \\
.160 \\
.160 \\
.160\end{array}$ & $\begin{array}{l}.200 \\
.170 \\
.160 \\
.160 \\
.160\end{array}$ & \\
\hline Average.. & & .168 & .172 & .171 & .169 & .170 \\
\hline $\begin{array}{l}\text { N } \\
\text { N } \\
\text { N } \\
\text { N } \\
\text { N }\end{array}$ & 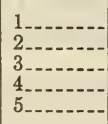 & $\begin{array}{l}.190 \\
.160 \\
.140 \\
.135 \\
.135\end{array}$ & $\begin{array}{l}.170 \\
.135 \\
.125 \\
.125 \\
.125\end{array}$ & $\begin{array}{l}.140 \\
.135 \\
.130 \\
.130 \\
.130\end{array}$ & $\begin{array}{l}.145 \\
.135 \\
.130 \\
.130 \\
.130\end{array}$ & \\
\hline Average & & .154 & .136 & .133 & .134 & 139 \\
\hline $\begin{array}{l}\mathrm{L} \\
\mathrm{L} \\
\mathrm{L} \\
\mathrm{L} \\
\mathrm{L} \\
\mathrm{L}\end{array}$ & 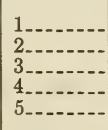 & $\begin{array}{l}.180 \\
.155 \\
.140 \\
.135 \\
.130 \\
\end{array}$ & $\begin{array}{l}.175 \\
.160 \\
.155 \\
.150 \\
.140 \\
\end{array}$ & $\begin{array}{l}.195 \\
.160 \\
.150 \\
.145 \\
.145 \\
\end{array}$ & $\begin{array}{l}.175 \\
.155 \\
.145 \\
.135 \\
.130 \\
\end{array}$ & \\
\hline Average & & .148 & .156 & .159 & .148 & .153 \\
\hline $\begin{array}{l}\mathrm{Q} \\
\mathrm{Q} \\
\mathrm{Q} \\
\mathrm{Q} \\
\mathrm{Q} \\
\mathrm{Q}\end{array}$ & \begin{tabular}{|l}
$1-\cdots$ \\
$2--\cdot$ \\
$3---$ \\
$4--\cdot-$ \\
$5--\cdot-$
\end{tabular} & $\begin{array}{l}.265 \\
.245 \\
.240 \\
.235 \\
.235\end{array}$ & $\begin{array}{l}.265 \\
.245 \\
.240 \\
.240 \\
.230\end{array}$ & $\begin{array}{l}.265 \\
.250 \\
.250 \\
.240 \\
.235\end{array}$ & $\begin{array}{l}.250 \\
.245 \\
.235 \\
.230 \\
.230\end{array}$ & \\
\hline Average........... & F & .244 & .245 & .248 & .238 & .244 \\
\hline
\end{tabular}


TABLE 9.-Friction measurements at $\% 0^{\circ} \pm 2^{\circ} \mathrm{F}$. and relative humidity of $65+2$ per cent-Continued

\begin{tabular}{|c|c|c|c|c|c|c|}
\hline \multirow{2}{*}{ Specimen } & \multirow{2}{*}{ Reading } & \multicolumn{5}{|c|}{ Coefficient of friction } \\
\hline & & Series 1 & Series 2 & Series 3 & Series 4 & $\begin{array}{l}\text { General } \\
\text { averate }\end{array}$ \\
\hline $\begin{array}{l}\mathrm{A} \\
\mathrm{A} \\
\mathrm{A} \\
\mathrm{A} \\
\mathrm{A}\end{array}$ & $\mid \begin{array}{l}1--- \\
2--- \\
3--- \\
4--- \\
5---\end{array}$ & $\begin{array}{r}0.275 \\
.270 \\
.265 \\
.265 \\
.265\end{array}$ & $\begin{array}{l}0.270 \\
.270 \\
.270 \\
.270 \\
.270\end{array}$ & $\begin{array}{l}0.280 \\
.270 \\
.270 \\
.270 \\
.270\end{array}$ & $\begin{array}{l}0.285 \\
.280 \\
.280 \\
.280 \\
.280\end{array}$ & \\
\hline A verage..- & & .268 & .270 & .272 & .281 & 0.273 \\
\hline 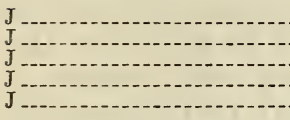 & $\mid \begin{array}{l}1 \\
2-\ldots \\
3-\ldots \\
4-\ldots \\
5-\ldots\end{array}$ & $\begin{array}{l}.435 \\
.405 \\
.390 \\
.385 \\
.385\end{array}$ & $\begin{array}{l}.440 \\
.400 \\
.380 \\
.365 \\
.365\end{array}$ & $\begin{array}{l}.450 \\
.405 \\
.385 \\
.375 \\
.365\end{array}$ & $\begin{array}{l}.425 \\
.375 \\
.355 \\
.345 \\
.335\end{array}$ & \\
\hline Average... & & .400 & .388 & .396 & .367 & .388 \\
\hline $\begin{array}{l}\mathrm{U} \\
\mathrm{U} \\
\mathrm{U} \\
\mathrm{U} \\
\mathrm{U} \\
\mathrm{U}\end{array}$ & $\begin{array}{l}1-\cdots \\
2-\cdots \\
3-\cdots \\
4-\cdots \\
5-\ldots\end{array}$ & $\begin{array}{l}.415 \\
.380 \\
.360 \\
.360 \\
.350\end{array}$ & $\begin{array}{l}.450 \\
.385 \\
.365 \\
.350 \\
.345\end{array}$ & $\begin{array}{l}.450 \\
.395 \\
.370 \\
.365 \\
.360\end{array}$ & $\begin{array}{l}.440 \\
.390 \\
.360 \\
.350 \\
.345\end{array}$ & \\
\hline Average.... & & .373 & .379 & .388 & .377 & .379 \\
\hline $\begin{array}{l}\mathrm{V} \\
\mathrm{V} \\
\mathrm{V} \\
\mathrm{V} \\
\mathrm{V}\end{array}$ & $\begin{array}{ll}1 \\
2 \\
3 \\
4 \\
5 \\
-\cdots-\cdots\end{array}$ & $\begin{array}{l}.340 \\
.295 \\
.280 \\
.270 \\
.265\end{array}$ & $\begin{array}{l}.385 \\
.330 \\
.300 \\
.285 \\
.275\end{array}$ & $\begin{array}{l}.360 \\
.310 \\
.290 \\
.285 \\
.280\end{array}$ & $\begin{array}{l}.355 \\
.310 \\
.290 \\
.270 \\
.270\end{array}$ & \\
\hline Average_... & & .290 & .317 & .305 & .300 & .303 \\
\hline
\end{tabular}

No attempt is made to predict from these data what precision can be obtained in standardized commercial friction tests on walk-way surface materials. Some indication of the agreement possible is given by a comparison of the measurements recorded in Table 9 , with measurements made on the same specimens in 1926. (See Table 10.)

Specimens $\mathrm{L}$ and $\mathrm{N}$ are omitted from Table 10. The worn surfaces of these specimens were slightly coated with an oxidized film in 1926 which had been removed in redressing them for the 1928 measurements, and for this reason the surfaces are not considered comparable. Since only three measurements were made on each of the specimens in 1926, the averages given for the 1928 measurements in Table 10 are for the first three measurements in each series.

TABLE 10.-1926 and 1928 friction measurements

\begin{tabular}{|c|c|c|c|c|c|c|}
\hline \multirow[b]{2}{*}{ Specimen } & \multicolumn{5}{|c|}{ Average coefficents of friction, 1928} & \multirow{2}{*}{$\begin{array}{c}\text { A verage, } \\
1926\end{array}$} \\
\hline & Series 1 & Series 2 & Series 3 & Series 4 & $\begin{array}{c}\text { Grand } \\
\text { average, } \\
\text { / } 1928\end{array}$ & \\
\hline 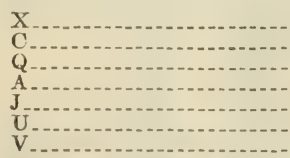 & $\begin{array}{r}0.180 \\
.178 \\
.250 \\
.270 \\
.410 \\
.385 \\
.305\end{array}$ & $\begin{array}{r}0.175 \\
.174 \\
.250 \\
.270 \\
.407 \\
.400 \\
.338\end{array}$ & $\begin{array}{r}0.173 \\
.178 \\
.255 \\
.273 \\
.413 \\
.405 \\
.320\end{array}$ & $\begin{array}{r}0.183 \\
.183 \\
.243 \\
.283 \\
.385 \\
.397 \\
.318\end{array}$ & $\begin{array}{l}0.178 \\
.181 \\
.250 \\
.274 \\
.403 \\
.397 \\
.320\end{array}$ & $\begin{array}{l}0.163 \\
.167 \\
.220 \\
.297 \\
.408 \\
.467 \\
.267\end{array}$ \\
\hline
\end{tabular}


While the averages of the 1926 and 1928 measurements are not strictly comparable, since there was only one series of three measurements on each specimen in 1926 and four series of three measurements each in 1928, they give the only information available as to what agreement may be expected in the results of tests made at different times. Considering that in commercial tests different specimens of each material and different observers will be employed, as close an agreement can not be expected, unless the method is further developed and standardized.

\section{SIMULATED SERVICE CONDITIONS}

There is no direct relation between the coeficients of friction on clean, dry surfaces and on the same materials under various actual service conditions. Few, if any, walk-way materials are dangerously slippery when clean and dry, but walk-way surfaces in actual use are not clean in the sense the term has been employed in this paper and are subject to ordinary atmospheric changes in humidity.

It is common experience that combinations of dirt and water or other fluids make some walk-way surfaces slippery. There is no evidence that any particular combination of dirt and water produces the most slippery surface alike on all walk ways or even on those most easily affected by such conditions. Consequently, there seems to be no possibility of selecting a single or even a limited number of actual service conditions which would adequately represent the various possible conditions on walk-way surfaces and which could be defined and accurately reproduced.

The only practical procedure seems to be to produce simulated service conditions by some selected or standard process and to measure and compare the coefficients of friction given by such surfaces.

\section{FRICTION MEASUREMENTS UNDER SIMULATED SERVICE CONDI- TIONS}

The measurements recorded in Tables 11 to 13, inclusive, were obtained in 1926 . These data are for specimens for which other data are given in preceding tables, and were selected as covering extreme ranges of roughness, hardness, and compressibility and as being fairly representative of general results obtained for wet and oily surfaces.

For the measurements on clean, wet surfaces the worn part of the specimen was wiped with a saturated cloth until a film of water stood over the entire worn surface. The specimen was then clamped in the apparatus and the friction measurement immediately made.

For the measurements on dirty, wet surfaces the same worn specimens were used and prepared as follows: A bag formed of four ply of cheesecloth was filled with the dust worn from the walk-way materials and leather in preparing the worn specimens, immersed in a vessel of water and worked about until a distinct residue formed in the bottom of the vessel. The worn part of the specimen and the test sole were then treated with the saturated bag lifted from the dirty water, as described for the clean, wet measurements.

For measurements on oil surfaces the specimens and soles were prepared in the same manner as for the measurements on clean, wet surfaces except that oil (medium Polarine) was used in place of water. 
For all measurements the test soles were prepared in the same manner as for measurements on dry surfaces up to the point of applying the water or oil, as the case might be. Immediately before the measurement on the specimen the sole was saturated with water or oil and passed over a piece of the same material as the sole, wet or oiled in the same manner as the test specimen and the sole.

The results of the friction measurements indicate that these processes do not produce the same surface conditions, even on the same specimens, but no better method has been discovered or suggested.

\section{TEST PROCEDURE ON WET AND OILY SURFACES}

It was observed when the coefficients of friction on wet or oily surfaces were measured that if the measurement was made as specified for a dry surface, a much higher value of the coefficient of friction would usually be obtained than on a clean, dry surface. This is especially marked on smooth-faced plane surfaces. It is less marked on ridged or otherwise roughened surfaces. A similar effect may be observed in walking over some wet surfaces. Frequently difficulty is experienced in obtaining a foothold in walking over a wet surface, but after firm contact between the shoe sole and the walk-way surface is made there is less tendency to slip than on a dry surface of the same material.

The apparently abnormally high values of coefficients of friction under these conditions may not be due to an actual increase in friction. They may be explained on the assumption that perfect contact is made and that a seal is formed between the wet or oily surfaces giving the effect of a partial vacuum under the shoe. If this is the case, the load produced by the difference in pressure is added to the vertical component of the thrust on the shoe, while the horizontal force remains equal to the horizontal component of the thrust. The true coefficient of friction would then be given by the ratio $\frac{F}{F^{\prime}+(A \times P)}$ in which $F$ is the horizontal and $F^{\prime}$ the vertical component of the thrust due to the 75-pound weight, $A$ is the area of contact in square inches, and $P$ is the differential pressure in pounds per square inch. The apparent coefficient as measured is $F / F^{\prime}$. There seems to be no way to avoid or definitely correct the error, as there is no means of determining how perfect a seal is formed or over what area perfect contact is made. However, if some means of evaluating $A$ and $P$, or the product $A \times P$, can be discovered, the corrected measurements and those on dry surfaces would have a similar significance, and they would have a much greater value in correlating laboratory measurements with actual service conditions than the uncorrected measurements.

Because of this obvious error, a double measurement was made on all wet and oily surfaces- $(a)$ An attempt to measure the difficulty of obtaining a foothold, and $(b)$ a measure of the coefficient of friction in the usual manner as on a dry surface. Measurement $(a)$ was obtained by raising the weight by increments of about 0.05 of an inch on the horizontal scale and partially releasing it after each increment until a position was reached where the shoe would grip the surface of the specimen and hold the weight. The lug was then 
moved to make contact with the shoe and its position recorded. The weight was then fully raised and the measurement $(b)$ taken.

Tables 11 to 13, inclusive, give data obtained in 1926 by the methods just described. Table 14 is a comparison of results from measurements made in 1926 with measurements made on the same specimens in 1929.

TABLE 11.-Coefficients of friction on clean, wet surface materials

\begin{tabular}{|c|c|c|c|c|}
\hline \multirow{2}{*}{ Material } & \multicolumn{4}{|c|}{ Coefficient of friction } \\
\hline & 1 & 2 & 3 & Average \\
\hline $\begin{array}{l}\mathrm{Q}(a) \\
\mathrm{Q}(b) \\
\text { W }(a) \\
\mathrm{L}(\mathrm{b})\end{array}$ & $\begin{array}{r}0.780 \\
.790 \\
.350 \\
.640 \\
.560 \\
.740\end{array}$ & $\begin{array}{r}0.770 \\
.770 \\
.220 \\
.625 \\
.560 \\
.720\end{array}$ & $\begin{array}{l}0.760 \\
.695 \\
.230 \\
.630 \\
.590 \\
.750\end{array}$ & $\begin{array}{l}0.770 \\
.752 \\
.267 \\
.632 \\
.570 \\
.737\end{array}$ \\
\hline $\begin{array}{l}\mathrm{P}(a) \\
\mathrm{P}(b) \\
\mathbf{V}(a)\end{array}$ & $\begin{array}{l}.750 \\
.820 \\
.810 \\
.855\end{array}$ & $\begin{array}{r}.640 \\
.790 \\
.830 \\
.880\end{array}$ & $\begin{array}{l}.610 \\
.770 \\
.855 \\
.865\end{array}$ & $\begin{array}{l}.667 \\
.793 \\
.832 \\
.867\end{array}$ \\
\hline
\end{tabular}

TABLE 12.-Coefficients of friction on wet, dirty surfaces

\begin{tabular}{|c|c|c|c|c|c|c|c|c|}
\hline \multirow{3}{*}{ Material } & \multicolumn{8}{|c|}{ Ceofficient of friction } \\
\hline & \multicolumn{4}{|c|}{ With leather sole } & \multicolumn{4}{|c|}{ With rubber sole } \\
\hline & 1 & 2 & 3 & Average & 1 & 2 & 3 & Average \\
\hline $\begin{array}{l}\text {Q} ~(a) \\
\text { Q }(b) \\
W(a) \\
\text { W (b) } \\
\text { L }(a)\end{array}$ & $\begin{array}{l}0.475 \\
.525 \\
.325 \\
.475 \\
.545 \\
.590\end{array}$ & $\begin{array}{l}0.430 \\
.485 \\
.325 \\
.450 \\
.525 \\
.585\end{array}$ & $\begin{array}{l}0.375 \\
.490 \\
.330 \\
.460 \\
.530 \\
.585\end{array}$ & $\begin{array}{r}0.427 \\
.500 \\
.327 \\
.462 \\
.533 \\
.587\end{array}$ & $\begin{array}{r}0.355 \\
.570 \\
.340 \\
.560 \\
.660 \\
.995\end{array}$ & $\begin{array}{l}0.355 \\
.640 \\
.385 \\
.625 \\
.650 \\
.995\end{array}$ & $\begin{array}{l}0.475 \\
.660 \\
.325 \\
.585 \\
.635 \\
.995\end{array}$ & $\begin{array}{r}0.395 \\
.623 \\
.348 \\
.590 \\
.648 \\
.995\end{array}$ \\
\hline $\begin{array}{l}\mathbf{P}(a) \\
\mathbf{P}(b) \\
\mathbf{V}(a) \\
\mathbf{V}(b)\end{array}$ & $\begin{array}{l}.360 \\
.460 \\
.820 \\
.845\end{array}$ & $\begin{array}{l}.385 \\
.505 \\
.790 \\
.820\end{array}$ & $\begin{array}{l}.380 \\
.525 \\
.800 \\
.810\end{array}$ & $\begin{array}{l}.375 \\
.497 \\
.803 \\
.825\end{array}$ & $\begin{array}{l}.345 \\
.585 \\
.710 \\
.750\end{array}$ & $\begin{array}{l}.370 \\
.585 \\
.675 \\
.770\end{array}$ & $\begin{array}{l}.385 \\
.585 \\
.675 \\
.750\end{array}$ & $\begin{array}{l}.367 \\
.585 \\
.687 \\
.757\end{array}$ \\
\hline
\end{tabular}

TABLE 13.-Coefficients of friction on oily surfaces

\begin{tabular}{|c|c|c|c|c|c|c|c|c|}
\hline \multirow{3}{*}{ Material } & \multicolumn{8}{|c|}{ Coefficients of friction } \\
\hline & \multicolumn{4}{|c|}{ With leather sole } & \multicolumn{4}{|c|}{ With rubber sole } \\
\hline & 1 & 2 & 3 & Average & 1 & 2 & 3 & Average \\
\hline $\begin{array}{l}\mathrm{Q}(a) \\
\mathrm{Q}(b) \\
W(a) \\
\mathrm{W}(b) \\
\mathrm{L}(a)\end{array}$ & $\begin{array}{r}0.200 \\
.215 \\
.090 \\
.100 \\
.185 \\
.305\end{array}$ & $\begin{array}{l}0.265 \\
.215 \\
.090 \\
.100 \\
.180 \\
.295\end{array}$ & $\begin{array}{r}0.300 \\
.225 \\
.090 \\
.100 \\
.165 \\
.205\end{array}$ & $\begin{array}{l}0.255 \\
.218 \\
.090 \\
.100 \\
.177 \\
.268\end{array}$ & $\begin{array}{l}0.270 \\
.375 \\
.120 \\
.215 \\
.205 \\
.340\end{array}$ & $\begin{array}{r}0.300 \\
.350 \\
.140 \\
.200 \\
.225 \\
.315\end{array}$ & $\begin{array}{l}0.315 \\
.330 \\
.145 \\
.200 \\
.225 \\
.315\end{array}$ & $\begin{array}{r}0.295 \\
.352 \\
.135 \\
.205 \\
.218 \\
.323\end{array}$ \\
\hline $\begin{array}{l}\mathrm{P}(a) \\
\mathrm{P}(b) \\
\mathrm{V}(a) \\
\mathrm{V}(b)\end{array}$ & $\begin{array}{l}.090 \\
.530 \\
.385 \\
.390\end{array}$ & $\begin{array}{l}.265 \\
.525 \\
.360 \\
.375\end{array}$ & $\begin{array}{l}.380 \\
.520 \\
.385 \\
.345\end{array}$ & $\begin{array}{l}.248 \\
.525 \\
.377 \\
.370\end{array}$ & $\begin{array}{l}.165 \\
.355 \\
.325 \\
.325\end{array}$ & $\begin{array}{l}.205 \\
.340 \\
.320 \\
.290\end{array}$ & $\begin{array}{l}.185 \\
.325 \\
.280 \\
.275\end{array}$ & $\begin{array}{l}.185 \\
.340 \\
.308 \\
.297\end{array}$ \\
\hline
\end{tabular}


TАBIE 14.-Coefficients of friction measured at different times on clean wet surfaces with leather soles

\begin{tabular}{|c|c|c|c|c|c|c|c|c|}
\hline \multirow{3}{*}{ Specimen } & \multicolumn{8}{|c|}{ Coefficients of friction } \\
\hline & \multicolumn{4}{|c|}{ Measured in 1926} & \multicolumn{4}{|c|}{ Measured in 1929} \\
\hline & 1 & 2 & 3 & A verage & 1 & 2 & 3 & Average \\
\hline $\begin{array}{l}\text { A }(a) \\
\text { A }(b) \\
\text { C }(a) \\
\text { C }(b) \\
\text { J }(a) \\
\text { J }(b)\end{array}$ & $\begin{array}{r}0.380 \\
.770 \\
.270 \\
.490 \\
.270 \\
.560\end{array}$ & $\begin{array}{r}0.360 \\
.770 \\
.220 \\
.485 \\
.315 \\
.610\end{array}$ & $\begin{array}{r}0.355 \\
.770 \\
.195 \\
.485 \\
.270 \\
.625\end{array}$ & $\begin{array}{r}0.365 \\
.770 \\
.228 \\
.487 \\
.285 \\
.598\end{array}$ & $\begin{array}{r}0.590 \\
.730 \\
.405 \\
.740 \\
.270 \\
.570\end{array}$ & $\begin{array}{r}0.570 \\
.730 \\
.390 \\
.750 \\
.325 \\
.615\end{array}$ & $\begin{array}{r}0.540 \\
.710 \\
.370 \\
.740 \\
.350 \\
.615\end{array}$ & $\begin{array}{l}0.567 \\
.723 \\
.388 \\
.743 \\
.315 \\
.600\end{array}$ \\
\hline $\begin{array}{l}\mathbf{L}(a) \\
\mathbf{L}(b) \\
\mathbf{P}(a) \\
\mathbf{P}(b)\end{array}$ & $\begin{array}{l}.560 \\
.740 \\
.750 \\
.820\end{array}$ & $\begin{array}{l}.560 \\
.720 \\
.640 \\
.790\end{array}$ & $\begin{array}{l}.590 \\
.780 \\
.610 \\
.770\end{array}$ & $\begin{array}{l}.570 \\
.737 \\
.667 \\
.793\end{array}$ & $\begin{array}{l}.510 \\
.625 \\
.750 \\
.780\end{array}$ & $\begin{array}{l}.490 \\
.650 \\
.760 \\
.730\end{array}$ & $\begin{array}{l}.485 \\
.675 \\
.750 \\
.770\end{array}$ & $\begin{array}{l}.495 \\
.650 \\
.753 \\
.760\end{array}$ \\
\hline $\begin{array}{l}\text { Q }(a) \\
Q(b) \\
\text { V }(a) \\
\text { V (b) }\end{array}$ & $\begin{array}{l}.780 \\
.790 \\
.810 \\
.855\end{array}$ & $\begin{array}{l}.770 \\
.770 \\
.830 \\
.850\end{array}$ & $\begin{array}{l}.760 \\
.695 \\
.855 \\
.865\end{array}$ & $\begin{array}{l}.770 \\
.752 \\
.833 \\
.857\end{array}$ & $\begin{array}{l}.580 \\
.650 \\
.615 \\
.590\end{array}$ & $\begin{array}{l}.570 \\
.640 \\
.635 \\
.570\end{array}$ & $\begin{array}{l}.590 \\
.660 \\
.660 \\
.560\end{array}$ & $\begin{array}{l}.580 \\
.650 \\
.638 \\
.573\end{array}$ \\
\hline $\begin{array}{l}\text { W }(a) \\
\text { W }(b) \\
\text { X }(a)\end{array}$ & $\begin{array}{l}.350 \\
.640 \\
.215 \\
.360\end{array}$ & $\begin{array}{l}.220 \\
.625 \\
.200 \\
.350\end{array}$ & $\begin{array}{l}.230 \\
.630 \\
.205 \\
.340\end{array}$ & $\begin{array}{l}.267 \\
.632 \\
.207 \\
.350\end{array}$ & $\begin{array}{l}.585 \\
.685 \\
.485 \\
.720\end{array}$ & $\begin{array}{l}.585 \\
.695 \\
.470 \\
.710\end{array}$ & $\begin{array}{l}.585 \\
.685 \\
.425 \\
.710\end{array}$ & $\begin{array}{l}.585 \\
.688 \\
.460 \\
.713\end{array}$ \\
\hline
\end{tabular}

\section{DISCUSSION OF FRICTION DATA}

In interpreting the preceding data it is important that the relative precision of the different measurements and the reasons for the lack of precision in particular measurements be understood.

The data in Tables 2 and 5 indicate that when constant surfaces are presented the apparatus will duplicate measurements to the nearest 0.005 , which is equivalent to an error of \pm 0.5 per cent for a coefficient of 0.5 or \pm 2.5 per cent for a coefficient of 0.1 . Measurements made on clean, dry surfaces (Table 10) show departures from the original series of measurements ranging for different materials from 0.5 to 9 per cent of the mean of the averages. Measurements on clean, wet surfaces (Table 14) show a wider divergence, ranging for different materials from 0.2 to 38 per cent of the mean.

The measurements on clean, dry surfaces show a reproducibility which would justify the assumption that the coefficient of friction of a material represents approximately its antislip value when the surface is clean and dry. However, it should be noted that some walkway materials tend to become slippery when the surfaces are dirty or wet or oily and that this tendency bears no relation to the coefficients of friction on clean, dry surfaces. For example, specimen J, a soft, smoothfaced, nonabsorbent material has a higher coefficient when the surface is clean and dry than specimen $V$, a roughened metal with abrasive embedded in its surface, while measurements on wet and oily surfaces of these same specimens give values in exactly the opposite order. 'Though these data would enable a rough rating of walk-way materials in respect to their antislip values under each of the simulated service conditions, their direct application to a safety provision for walk-way surfaces seems to be limited, unless the method is further developed and the friction measurements are correlated with the slipping hazard of walk ways in actual service. 
The spread in different determinations of the coefficient of friction of the same material, and the possible error in determining the minimum coefficient needed for safety from the meager data available are too great in comparison with the total range in the coefficients of friction of available materials to admit of a strict rating without introducing inconsistencies.

A rough classification of walk-way materials in respect to their safety values under different service conditions could be made from data obtainable by the methods described. This might be accomplished by arranging the materials in the order of their coefficients under each of the simulated service conditions, clean and dry, clean and wet, dirty and wet, and oily. It could be safely assumed that two materials having approximately the same coefficients on clean, dry surfaces will have approximately the same safety values in walk ways with clean, dry surfaces. It could also be safely assumed that two materials showing approximately the same coefficients on clean, wet surfaces will have approximately the same safety values for walk ways with surfaces in that condition, irrespective of what their coefficients are for clean, dry surfaces, and similarly for other simulated or assumed service conditions. Some rule of interpretation embodying these principles is essential before any rational rating of walk-way materials in respect to their safety or antislip values under actual service conditions can be made.

\section{SUMMARY OF CONCLUSIONS}

1. The apparatus developed for measuring coefficients of friction on walk-way surface materials will duplicate or reproduce its measurement of a given constant coefficient of friction to the nearest 0.005 .

2. The coefficient of friction between two materials is a constant only when the condition of the two surfaces remains constant.

3. The coefficient of friction between a shoe sole and a walk-way surface is a variable depending on the smoothness, cleanness, and moisture content of the two surfaces.

4. The precision with which the coefficient of friction between the same sole and the same walk-way material can be reproduced at different times depends on the exactness with which the smoothness, the cleanness, and the dryness can be reproduced, and it varies for different materials.

5. Characteristic differences in frictional properties of walk-way material are shown by their coefficients of friction, measured under dry, wet, and oily conditions, which indicate the tendencies of the materials to become slippery under various service conditions.

Washington, March 26, 1929. 